DOI: $10.14451 / 2.151 .7$

\title{
НОВЕЛЛЫ КОНСТИТУЦИОННОГО ЗАКОНОДАТЕЛЬСТВА В РАМКАХ ПРИНЯТЫХ ПОПРАВОК В КОНСТИТУЦИЮ РФ
}

\author{
(c) 2021 Казанкова Татьяна Николаевна \\ кандидат педагогических наук \\ Самарский государственный экономический университет, Россия, Самара \\ (c) 2021 Кузьмина Ирина Юрьевна \\ магистрант \\ Самарский государственный экономический университет, Россия, Самара
}

В рамках данной статьи рассматриваются современные тенденции кодификации российского законодательства, в частности в связи с изменениями, которые были внесены в Конституцию РФ.

Ключевые слова: кодификация, Конституция РФ, поправки, законодательство, Президент РФ, исполнительная власть.

Достаточно актуальной является проблема кодификации российского законодательства, в частности, в области конституционного права, и активно обсуждается в работах ученых-юристов, так и ученых практиков, как в России, так и в зарубежных странах. Кодификация законодательства занимает центральное место в правовой науке в целом. Благодаря кодификации можно упорядочить правовые нормы, соблюсти логику в правовом регулировании. На сегодняшний день есть несколько способов кодификации это как принятие поправок в действующие законодательство, так и создание нового сводного акта. Тема кодификации является актуальной не только в рамках Информационного кодекса, но и принятии поправок в действующую Конституцию РФ.

Современные тенденции кодификации российского законодательства, в частности связаны с изменениями, которые были внесены в Конституцию РФ. Этот вопрос затрагивает интересы не только каждого жителя современной России, но и новые поколения, которым еще только предстоит родиться: поправки вносятся на десятилетия, а возможно, на века. Предложенные изменения и уже принятые изменения Конституции расширяют и конкретизируют социальные гарантии, закрепляют на конституционном уровне особую защиту прав детей, возводят в ранг приоритетов целостность и независимость нашего государства.

В России уже 1 июля 2020 г. прошло общенародное голосование по поводу принятия конституционных поправок. Практически более 70\% проголосовавших была «за» внесение новых поправок в Конституцию РФ. Итак, выделим условно три категории принятых поправок (рис. 1).

Первым блоком поправок являются поправки, которые направлены на реформирование власти, в особенности статуса Президента РФ. Рассмотрим несколько основных поправок. В соответствии с принятыми поправками в ч. 3 ст. 81 Конституции РФ ограничивается число сроков, в течение которых одно и тоже лицо может занимать должность Президента без учета прежних занимаемых сроков.

Таким образом, получается, что произошло так называемое «обнуление» президентских сроков. Большая часть населения согласно социологическим опросам $48 \%$ одобряли данную

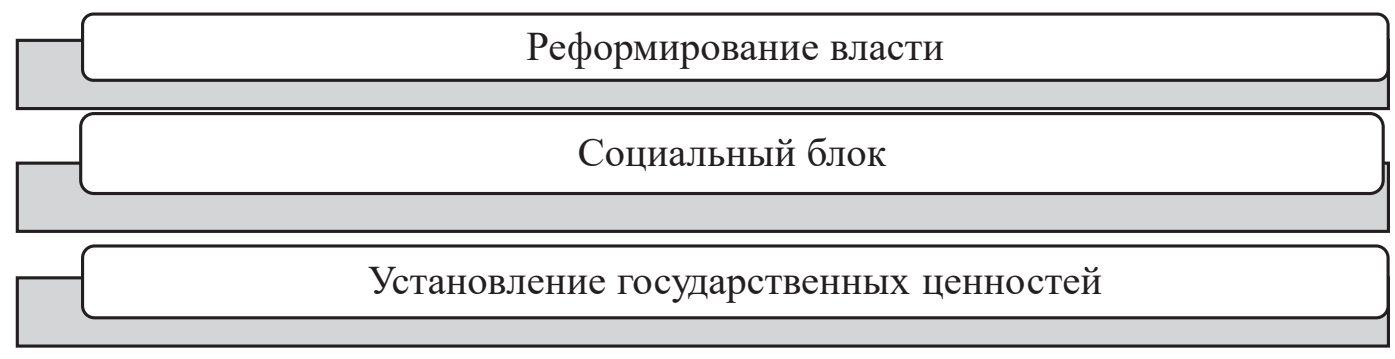

Рисунок 1. Категории поправок в Конституцию РФ на 2020 г. 
поправку, 47\% - встретили поправку резко негативно [2]. Кроме того, был введен запрет для одного человека занимать президентский пост более двух сроков. Ранее данная формулировка выглядела как «более двух сроков подряд». Получается таким образом, что выйти на третий срок одно и тоже лицо не сможет.

Также вводится понятие неприкосновенности президента, который прекратил полномочия в связи с истечением срока либо его отставки. Введение понятие неприкосновенности президента в данном случае говорит о том, что действующий президент может принимать все необходимые решения по охране суверенитета при ведении внутренней и внешней политики, и при этом как в момент, так и после прекращения исполнения полномочий не может быть привлечен к ответственности за ранее принятые решения. Однако, экс-президент может быть лишен неприкосновенности только лишь по инициатива Государственной Думы РФ или решения Верховного Суда РФ. Таким образом, единственной нормой привлечения к ответственности остался лишь импичмент.

Кроме того, после отставки экс-президент имеет право на пожизненною должность в Совете Федерации в соответствии с ст. 95 Конституции РФ. Данная должность связана с «пожизненным сенаторством». Таким образом, бывший Президент РФ может оставаться у власти и оказывать влияние на политические процессы, происходящие в стране. С одной стороны данное обстоятельство является положительным моментом, так как «пожизненный сенатор» будет с большим опытом в области управления страной, с другой стороны встает вопрос об злоупотреблении властью.

Еще одной не менее важной поправкой является расширение полномочий Президента РФ в области исполнительной власти. Президент РФ теперь не только «глава государства», но и глава исполнительной власти. Отметим, что ранее Президент РФ оказывал влияние на формирование Правительства РФ, и даже мог присутствовать на заседаниях. Теперь исполнительную власть Правительство РФ осуществляет под общим руководством Президента РФ в соответствии с п. «б» ст. 83. Отметим, что в соответствии с п. «в.1» ст. Конституции РФ Президент имеет право снять отдельно Председателя Правительства РФ, министров и руководителей федеральных органов без отставки всего Правительства
РФ. Также без одобрения парламента Президент РФ по своему усмотрению может назначать Премьер-министра РФ.

Также Президент РФ имеет право сам определять какими федеральными органами он руководит самостоятельно, а какими будет руководить Премьер-министр РФ, в соответствии с п. «б1» ст. 83 Конституции РФ. Ранее такого разделения власти между Президентов РФ и Премьерминистром не было, последний являлся единственным руководителем кабинета министров.

Не обошли стороной поправки в области судебной власти. Теперь в соответствии пунктом «е» ст. 83 Конституции РФ глава государства имеет право отправить в отставку как судей Конституционного Суда РФ, так и Верховного Суда РФ включая председателей и заместителей судей. Ранее данное право отсутствовало в Конституции РФ. Таким образом, исходя из принятых поправок мы видим, что полномочия, как и гарантии Президента РФ были расширены. Теперь на официальном уровне можно говорить о том, что глава государства - это глава исполнительной власти. Подобные изменения в Конституции РФ теперь надолго породили дискуссионный вопрос о применении принципа разделения властей в Российской Федерации. Кроме того, пока относительно рано судить о положительных или отрицательных моментах в расширении полномочий Президента РФ.

Изменения также коснулись, и Конституционного Суда РФ. Во-первых, полномочия Конституционного Суда РФ были расширены в области проверки на конституционность законопроекта по запросу Президента РФ перед его подписанием. Данная поправка направлена на то, чтобы минимизировать правовые коллизии и правовые пробелы при принятии того или иного нормативно-правового акта.

Гарантом конституционности действующих законов и, в случае сомнений в этом, является единственным органом, имеющим полномочия на толкование Конституции в определенном разрезе и установлении конституционности оспариваемых положений является непосредственно Конституционный Суд РФ. В системе разделения властей Конституционный Суд РФ является неотъемлемым элементом, обеспечивающим функционирование остальных органов власти и укрепление законности на территории России.

Во-вторых, сократился состав суда с 19 судей 
до 11 судей включая Председателя Конституционного Суда РФ и его заместителя. По мнению профессора Е.Лукьяновой [3] снижение количества судей в Конституционном Суде РФ может отразиться на эффективности работы Конституционного Суда РФ. Это связано с тем, что в суд поступает большое количество обращений, а также Конституционный Суд не может рассматривать два дела одновременно, таким образом нарушается конституционное право на судебную защиту. С данной точкой зрения нельзя согласится, потому что данная поправка основана на сложившейся практике в последние годы, так как фактически состав Конституционного Суда РФ состоял из 15 судей, а не из 19 как было закреплено ранее в Конституции РФ. Кроме того, в «усеченном» составе Конституционный Суд РФ показал возможность справляться с поставленными задачи в полном объеме.

Во-третьих, Конституционный Суд РФ получил новую функцию - оценка исполнения решений международных институтов. Как утверждает законодатель данная функция необходима для того, чтобы защитить суверенитет России. Теперь в рамках данной функции Конституционный Суд РФ устанавливает возможность исполнения решений не только межправительственных органов, но и иностранных судов и арбитражей в случае их противоречия основам публичного порядка в РФ. Таким образом, требования и решения международных договоров могут действовать лишь в той части, в которой они про противоречат Конституции РФ, получается приоритет национального права над международным правом. По словами министра иностранных дел С.Лаврова данная ситуация не является уникальной, такой приоритет существует также в западных странах таки как Германия и Великобритания.

Второй категорией принятых поправок стали поправки в области социального блока. Прежде всего социальные поправки направлены на улучшение материального положения граждан РФ. Ранее в ст. 75 Конституции РФ говорилось о том, что государство охраняет труд и здоровье людей и устанавливает гарантированный MPOT. Теперь принятые поправки дополняют в полном объеме ст. 7 Конституции РФ устанавливая МРОТ не менее прожиточного минимума на территории всей Российской Федерации. Также были внесены поправки касательно пенсионных выплат. Согласно внесённым поправкам в РФ сформирована система пенсионного обеспечения граждан, основанная на трех принципах, которые отражены на рисунке 2.

Индексация пенсии происходит не реже 1 раза в год, в соответствии с установленным федеральным законом. Кроме того, обязательной индексации подлежат и другие социальные выплаты.

Еще одной значительной принятой поправкой является гарантия со стороны государства «гарантия благосостояния граждан РФ». В соответствии с ст. 751 в РФ будут созданы условия для устойчивого экономического роста страны и повышения благосостояния граждан. Кроме того, гарантируется защита граждан и уважение труда. Государство стремится сбалансировать права и обязанности гражданина, социальное партнерство, политическую и социальную солидарность. Данная поправка говори о том, что государство стремится улучшить благосостояние граждан в экономической, социальной и политических областях. Таким образом можно говорить о том, что государство стремиться создать гражданское общество и правовое государство в целом.

Третья категория поправок принятая в Конституцию РФ является установление государственных ценностей. Первой государственной ценностью является непосредственно институт семьи. В соответствии с ч. 1 п. Ж1 ст. 72 со стороны государства гарантируется защита детства, материнства и отцовства, кроме того, гаранти-

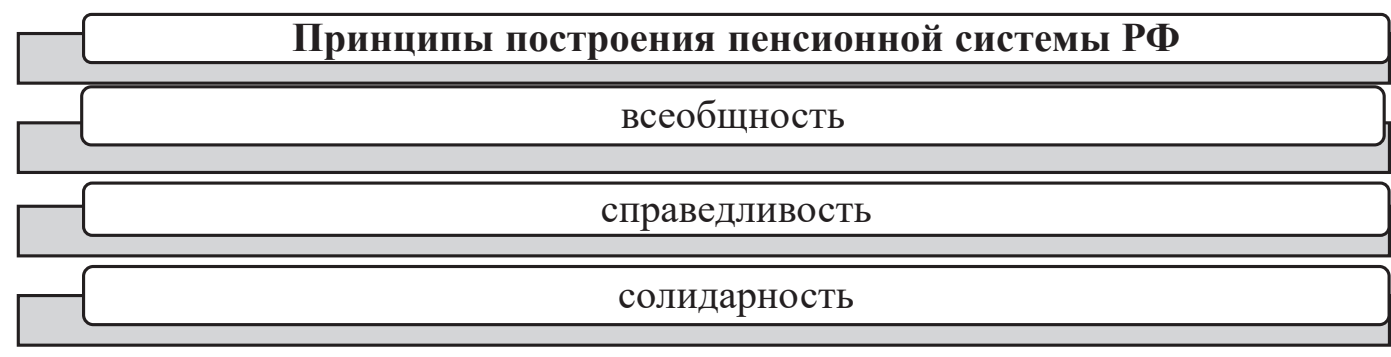

Рисунок 2. Основные принципы построения пенсионной системы в РФ 
руется создание условий для достойного воспитания детей, а также осуществления совершеннолетними детьми обязанностями по уходу за престарелыми родителями. Данная поправка Конституции РФ является одной из важнейших поправок. Так как самые не защищённые слои населения (старики и дети) получают дополнительные гарантии со стороны государства.

В соответствии с ч. 4 ст. 67 Конституции РФ гарантируются условия для интеллектуального, физического, нравственного развития детей, воспитания патриотизма и гражданственности. В РФ гарантируется приоритет семейного воспитания. Кроме того, государство признает приоритетным направлением внутренний политики - развитие и воспитание детей. Также оно берет на себя ответственность за воспитание детей, которые остались без попечения родителей. Данные поправки уже сейчас можно считать положительными, так как именно от воспитания поколений зависит будущее нашего государства. Резонансной поправкой является поправка в области признания брака только лишь союза между мужчиной и женщиной. Таким образом, в России на законодательном уровне закрепилась традиционная модель института семьи.

Также поправки коснулись русского языка как государственного языка. Русский язык признается языком государственнообразующего народа, входящего в состав многонациональный союз равноправных народов РФ в соответствии с ч. 1 ст. 68 Конституции РФ. Согласно позиции Конституционного суда РФ [4] представленная поправка является беспристрастной. Так как роль русского народа в образовании российского государственности является значительной. Кроме того, данная поправка не ущемляет достоинства других 180 национальностей проживающих на территории России. Были внесены поправки касаемо культуры России, где культура признается уникальным наследием всех национальностей проживающих на территории РФ.

Государство также внесло поправки по защите исторической правды. Однако данное обстоятельство было встречено негативной критикой со стороны ученых-правоведов. В частности, по мнению юриста А. Ковольчука [5] данная поправка не должна была быть закреплена как норма права, данную поправку необходимо было внести в преамбулу Конституции РФ. Как отмечает автор, историческая правда не смотря на моральное значение представляет собой в первую очередь научное явление и не имеет, и не может иметь установленную форму. Именно данная поправка является очень спорной не как этическое требование, а именно как правовая норма, в частности если она будет подкреплена в дальнейшим санкциями административного или уголовного законодательства.

Таким образом, принятые поправки в Конституцию РФ были весьма спорными как для ученых-юристов, так и для простых граждан. Так или иначе данные поправки приняты. Судить об их эффективности можно только лишь спустя определенное время. Данные поправки были направлены не только на расширение полномочий Президента РФ, но прежде всего данные поправки были направлены на благосостояние граждан России.

\section{Библиографический список}

1. Конституция Российской Федерации [Электронный ресурс].- Режим доступа: http://www.consultant.ru/ document/cons_doc_LAW_28399/ (дата обращения 09.09.2020 г.)

2. ВЦИОМ Аналитический обзор «Что думают россияне о поправках в Конституцию РФ?» [Электронный pecypc].- Режим доступа: https://wciom.ru/index.php?id=236\&uid=10196\&utm_source=yxnews\&utm_ medium=desktop\&utm_referrer=https\%3A\%2F\%2Fyandex.ru\%2Fnews (дата обращения 09.09.2020 г.)

3. Лукьянова Е. Анализ поправок в Конституцию РФ [Электронный ресурс].- Режим доступа: https://hrcspb. org/2020/01/26/elena-luk-yanova-o-popravkah-k-konstitutsii-rf/ (дата обращения 09.09.2020 г.)

4. Заключение Конституционного Суда РФ от 16.03.2020. [Электронный ресурс]. - Режим доступа: http://doc. ksrf.ru/decision/KSRFDecision459904.pdf (дата обращения 09.09.2020 г.)

5. Ковальчук А. Об «исторической правде» в поправках к Конституции РФ [Электронный ресурс].- Режим доступа: https://zakon.ru/blog/2020/6/14/ob_istoricheskoj_pravde_v_popravkah_k_konstitucii_rf (дата обращения 09.09.2020 г.) 